\title{
Sampublisering av systematiske oversikter
}

Det er alltid risikabelt å fatte beslutninger på bakgrunn av én enkelt undersøkelse, enten det dreier seg om organisatoriske eller pasientrettede tiltak. Tilfeldigheter, feil eller andre omstendigheter kan føre til misvisende resultater selv i store og solide studier. På områder der det finnes mange gjennomførte og publiserte undersøkelser, er det dessuten fare for at man baserer seg på enkeltstudier som ikke er representative, men som velges fordi funnene passer med egen erfaring eller egne interesser. Slik selektiv bruk av forskningsresultater, «cherry picking», er en viktig potensiell feilkilde i beslutningsprosesser.

For å sikre et så godt kunnskapsgrunnlag som mulig, er det nødvendig å innhente og gjennomgå alle tilgjengelig studier som er utført av et aktuelt tiltak eller en aktuell problemstilling. Produktet av en prosess der man leter etter alle utførte studier fra hele verden, vurderer hvor holdbare funnene er og sammenfatter resultatene, kalles en systematisk oversikt (1). Kan dataene fra ulike studier samles og reanalyseres, kalles det en metaanalyse (2). Langt fra alle systematiske oversikter ledsages av en metaanalyse. Det skyldes vanligvis at de utvalgte delstudiene er så ulike (heterogene) at forutsetningene for å gjøre det, er brutt.

Systematiske oversikter er et viktig grunnlag for kunnskapsbaserte beslutninger i helsetjenesten. I tillegg til at de gir mer presis kunnskap om effekten av tiltak og andre sammenhenger, blir også påliteligheten av den foreliggende dokumentasjonen vurdert (3). Kunnskapssenteret for helsetjenesten, som fra 2016 er en del av Folkehelseinstituttet, har som en av sine hovedoppgaver å utarbeide systematiske oversikter for å understøtte gode beslutninger på bestilling fra helseforvaltningen, helsetjenesten og profesjons- og brukerorganisasjoner. Noen systematiske oversikter inngår i internasjonale publikasjoner, men de fleste blir publisert i form av norskspråklige rapporter.

Slike rapporter når imidlertid sjelden et stort publikum. Derfor har Tidsskriftet og Kunnskapssenteret etablert et samarbeid for å publisere en artikkelversjon av oversikten samtidig som den fullstendige rapporten blir offentliggjort. Når arbeidet med en rapport er 4-6 måneder fra ferdigstillelse, utarbeider forfatterne et artikkelmanuskript og sender det inn for vurdering på vanlig måte. Kvalitetskravene er selvsagt de samme som for andre manuskripter, men det må legges en tidsplan som er strammere enn vanlig. På mange måter ligner dette en form for «fast track»-vurdering, noe flere internasjonale tidsskrifter tilbyr. Som medisinsk redaktør har Geir Wenberg Jacobsen hovedansvar for prosjektet, og det første resultatet foreligger i denne utgaven av Tidsskriftet (4). Et lite knippe faglige medarbeidere ble kontaktet på forhånd og hadde sagt seg villig til å bidra til en rask manuskriptvurdering. Tiden fra første innsending til godkjenning, inkludert flere runder mellom forfattere og redaksjon, var 89 dager, det vil si under en tredel av median behandlingstid for originalartikler i Tidsskriftet (5).

Artikkelen til Larun og medarbeidere (4) er basert på en bestilling fra Norsk forening for allmennmedisin og har resultert i en egen rapport (6). Oppdraget var å klarlegge nytten av skjemabasert oppfølging av pasienter med diabetes i allmennpraksis. Norsk kvalitetsforbedring av laboratorievirksomhet utenfor sykehus (NOKLUS) har utarbeidet et oppfølgingsskjema for bruk i allmennpraksis (7) som anbefales av Helsedirektoratet. Det er påfallende at bare i én av de syv inkluderte studiene i oversikten ble effekten av skjemabruk på primære endepunkter som dødelighet, hjerteinfarkt og hjerneslag undersøkt, og skjemabruk hadde ikke noen effekt på disse. Samtidig som oversikten viser en tendens til effekt på noen av sekundærmålene, er det verdt å legge merke til at den statistiske signifikansen er mer åpenbar enn den kliniske relevansen. Forfatterne formidler da også en klar henstilling til det allmennmedisinske fagmiljøet om at «mer forskning» er nødvendig.

Vi håper at dette er innledningen til et langvarig og fruktbart samarbeid om artikkelpublisering av systematiske oversikter, som kanskje kan etterfølges av andre forskningsgrupper som i hovedsak publiserer rapporter. En av utfordringene blir å finne temaer med tilstrekkelig relevans for Tidsskriftets lesere. Dernest behøves samarbeidsvillige oppsummeringsbestillere, motiverte og dedikerte forfattere, godt forberedte fagvurderere, en stram, men realistisk tidsplan og en stab på begge sider av bordet som ser nytten i denne publiseringsmåten.

Det har vært diskutert i akademiske kretser om publikasjoner som presenterer systematiske kunnskapsoversikter er såkalt høyverdige nok til at de for eksempel kan utgjøre selvstendige delarbeider i en ph.d.-avhandling. Den diskusjonen bør være over. Utarbeiding av systematiske oversikter - med eller uten metaanalyser - er ikke bare original forskning, det er dessuten viktig og nyttig forskning, noe den aktuelle artikkelen viser. Det er grunnen til at Tidsskriftet har sjangerplassert den som originalartikkel.

\section{Geir Wenberg Jacobsen}

geir.jacobsen@legeforeningen.no

Magne Nylenna

Geir Wenberg Jacobsen (f. 1945) er medisinsk redaktør i Tidsskriftet og professor emeritus ved Det medisinske fakultet, Norges teknisknaturvitenskapelige universitet. Han har vært en av initiativtakerne til samarbeidsprosjektet.

Forfatter har fylt ut ICMJE-skjemaet og oppgir ingen interessekonflikter

Magne Nylenna (f. 1952) er direktør for Kunnskapssenteret i Folkehelseinstituttet og professor II i samfunnsmedisin ved Universitetet i Oslo. Forfatter har fylt ut ICMJE-skjemaet og oppgir ingen interessekonflikter.

Litteratur

1. Jamtvedt G. Systematiske oversikter om effekt av tiltak. Norsk Epidemiologi 2013: 23: 119-24. www.ntnu.no/ojs/index.php/norepid/article/view/1632 (25.2.2016).

2. Smedslund G. Metaanalyse. Norsk Epidemiologi 2013; 23: 147-9. www.ntnu.no/ ojs/index.php/norepid/article/view/1636 (25.2.2016)

3. Vist GE, Sæterdal I, Vandvik PO et al. Gradering av kvaliteten på dokumentasjonen. Norsk Epidemiologi 2013; 23: 151-6. www.ntnu.no/ojs/index.php/norepid/ article/view/1637 (25.2.2016)

4. Larun L, Bjørner T, Fretheim A et al. Bruk av skjema i oppfølgingen av diabetes i allmennpraksis. Tidsskr Nor Legeforen 2016; 136: 417-22.

5. Tidsskrift for Den norske legeforening. Forfatterveiledning. Originalartikkel. Artikler basert på egne innsamlede og bearbeidede data. http.//tidsskriftet.no/ Innhold/Forfatterveiledningen/Artikkeltyper/Originalartikkel (25.2.2016).

6. Larun L, Kirkehei I, Rygh OM et al. Bruk av skjema i oppfølgingen av diabetes i allmennpraksis - en systematisk oversikt og meta-analyse. Rapport fra Kunnskapssenteret. Oslo: Folkehelseinstituttet, 2016.

7. NOKLUS diabetesskjema. www.diabetes.no/ NOKLUS+diabetesskjema.b7C_wlfUYK.ips (25.2.2016). 